\title{
INTERFERENSI BAHASA BETAWI DI KAMPUNG GONDRONG KOTA TANGERANG
}

\author{
Agus Sulaeman ${ }^{* 1}$, Ahmad Suherman $^{2}$, Mutoharoh $^{3}$ \\ ${ }^{1,3}$ Universitas Muhammadiyah Tangerang, ${ }^{2}$ Universitas Singaperbangsa Karawang \\ Jalan Perintis Kemerdekaan I Babakan No.33, Cikokol, Kec. Tangerang, \\ Kota Tangerang, Banten, Indonesia \\ Email: sultanwahyu13@gmail.com ${ }^{* 1}$, achmad.suherman2@gmail.com², \\ mutoharoh@gmail.com ${ }^{3}$
}

\begin{abstract}
Abstrak
Tujuan penelitian ini adalah untuk mendeskripsikan interferensi bahasa Betawi pada percakapan masyarakat Kampung Gondrong, Cipondoh, Kota Tangerang. Metode penelitian yang digunakan adalah deskriptif kualitatif. Data dalam penelitian ini adalah dari bahasa lisan masyarakat petutur di Desa Gondrong, Kota Tangerang. Penentuan wilayah penelitian ditentukan berdasarkan letak tempat tinggal peneliti. Adapun informan penelitian ini, yaitu: penutur asli bahasa yang diteliti, tidak memiliki kelainan dalam pelafalan, dan memiliki daya ingat yang baik. Instrumen dalam penelitian ini adalah peneliti sendiri dibantu dengan tabel interferensi morfologis dan tabel struktur fonologis. Penelitian ini menggunakan teknik wawancara, yakni percakapan dianalisis dengan memperhatikan tiap-tiap kata. Data direkam, disimak, dan dicatat. Hal ini untuk melengkapi data yang sudah terkumpul. Analisis data menggunakan metode padan dan agih dengan berbagai teknik yang disesuaikan karakter data yang diperoleh dan tujuan penelitian. Selanjutnya, kata yang menunjukan adanya gejala interferensi morfologis dan fonologis digaris bawahi dan dicatat, selanjutnya kata-kata tersebut dicek kebenarannya dengan menggunakan Kamus Besar Bahasa Indonesia. Hasil penelitian menunjukkan bahwa masyarakat Kampung Gondrong melakukan interferensi morfologis bahasa Betawi dalam dialog sehari-hari. Bentuk-bentuk interferensi yang terdapat pada dialog adalah bentuk kata dan imbuhan (afiks). Bentuk imbuhan yang terinferferensi adalah bentuk prefiks, sufiks, dan konfiks, sedangkan interferensi pada bentuk infiks tidak dijumpai.
\end{abstract}

Kata kunci: interferensi, bahasa Betawi, percakapan sehari-hari

\section{BETAWI LANGUAGE INTERFERENCE IN GONDRONG VILLAGE TANGERANG CITY}

\begin{abstract}
The purpose of this study was to describe the Betawi language interference in the conversations of the people of Gondrong Village, Cipondoh, Tangerang City. The research method used is descriptive qualitative. The data in this study were from the spoken language of the native speakers in Gondrong Village, Tangerang City. Determination of the research area is determined based on the location where the researcher lives. The informants of this study, namely: native speakers of the studied language, had no abnormalities in pronunciation, and had good memory. The instrument in this study was the researcher himself assisted by morphological interference tables and phonological structure tables. This study uses interview
\end{abstract}


techniques, namely conversations are analyzed by paying attention to each word. Data recorded, listened to, and recorded. This is to complement the collected data. Data analysis used the match and divide method with various techniques adapted to the character of the data obtained and the research objectives. Next, words that show signs of morphological and phonological interference are highlighted and recorded, then the correctness of the words is checked using the Big Indonesian Dictionary. The results showed that the people of Gondrong Village conducted morphological interference in the Betawi language in their daily dialogues. The forms of interference contained in the dialogue are words and affixes (affixes). The form of affix that is inferenced is the form of prefix, suffix, and confix, while the interference in the infix form is not found.

Keywords: interference, Betawi language, daily conversation

\section{A. Pendahuluan}

Indonesia adalah salah satu negara kepulauan di Asia Tenggara yang wilayahnya sangat luas, dari Sabang sampai Merauke, dengan penduduknya yang terdiri atas berbagai suku bangsa (etnis) dengan bahasa, adat-istiadat dan budaya yang berbeda. Salah satu dari suku bangsa yang banyak itu adalah etnis Betawi yang merupakan penduduk asli di Kota Jakarta dan wilayah sekitarnya. Bahasa atau dialek Betawi ini sudah banyak dikaji orang. Hasil kajiannya pun sudah banyak yang diterbitkan. Sampai sekarang bahasa Betawi, termasuk dialeknya, masih hidup di masyarakat walaupun ada beberapa yang mengalami pergeseran dialek (Tiani, 2018).

Sebagaimana etnis lain, orang Betawi atau etnis Betawi ini pun memiliki bahasa sendiri, yaitu bahasa Betawi yang secara linguistis-histori merupakan salah satu dialek areal dari bahasa Melayu (Dewi dkk., 2020). Selain itu, berbeda dengan kedudukan bahasa-bahasa daerah dan bahasa Melayu lokal lainnya, bahasa Betawi, mempunyai peran penting yang amat khas terhadap perkembangan bahasa Indonesia. Kedudukannya itu ditentukan, baik karena struktur internal bahasa berkat sejarahnya yang unik, maupun karena kebetulan berlokasi di Ibu Kota Republik Indonesia dan sekitarnya.

Bahasa Betawi merupakan bahasa yang banyak mengadopsi dari bahasa Melayu. Kekhasannya dialek Betawi yang berada di wilayah Jakarta Tengah yang paling menonjol yaitu hampir semua kata diakhiri dengan huruf vokal "e", sedangkan dialek Betawi pada daerah Jakarta pinggiran hampir semua kata diakhiri dengan huruf vokal "a" (Alfianika, 2015). Tidak hanya itu, bahasa Betawi 
terbiasa meninggikan intonasi ketika sedang berbicara dengan lawan bicaranya. Bahasa betawi merupakan bahasa yang dikenal orang kurang memikirkan akan peraturan atau dikenal dengan istiilah "Nyablak". Keunikan dalam bahasa Betawi masih banyak ditemukan di daerah Cipondoh Kota Tangerang tepatnya di Kampung Gondrong.

Dalam berkomunikasi tentunya setiap masyarakat menggunakan sebuah bahasa untuk bisa berinteraksi, dengan tujuan agar penutur dapat mengungkapkan pendapat serta penutur dapat memahami apa yang diutarakan oleh penutur lain. Menurut Chaer (2010:11) dan Noermanzah (2019) bahasa adalah alat komunikasi berupa sistem, artinya bahasa itu dibentuk oleh sejumlah komponen yang berpola secara tetap dan dapat dikaidahkan. Sedangkan menurut Suhardi (2013) bahasa adalah sistematik, yaitu memiliki aturan atau pola. Aturan tersebut dapat dilihat melalui dua hal, yaitu sistem bunyi dan sistem makna.

Dalam masyarakat Indonesia, karena banyak terdiri dari suku dan berbagai macam bahasa, maka setiap bahasa memiliki variasi bahasa tersendiri. Menurut Chaer (2010) variasi pertama berdasarkan penuturnya adalah variasi bahasa idiolek, yakni variasi bahasa yang bersifat perseorangan. Menurut konsep idiolek, setiap individu mempunyai variasi bahasanya atau idiolek masing-masing. Variasi bahasa kedua adalah dialek, yakni variasi bahasa dari sekelompok penutur yang jumlahnya relatif, yang berada pada satu tempat, wilayah, atau area tertentu. Dialek ini didasarkan pada wilayah atau area tempat tinggal penutur, maka dialek ini lazim disebut dialek areal, dialek regional atau dialek geografi. Variasi bahasa ketiga disebut kronolek atau dialek temporal, yakni variasi bahasa yang digunakan oleh kelompok sosial pada masa tertentu. Variasi bahasa keempat adalah sosiolek atau dialek sosial, yakni variasi bahasa yang berkenaan dengan status, golongan, dan kelas sosial para penuturnya.

Berkaitan dengan bahasa, sesuai dengan penelitian yang menyangkut tentang bahasa Betawi atau dialek Betawi. Menurut Muhasyim (2011) kata Betawi berasal dari kata Batavia, yaitu nama lama Jakarta pada masa Hindia Belanda. 
Kata Betawi dipakai untuk menyatakan suku asli yang menghuni Jakarta, bahasa Melayu Kreol yang dipakai dan kebudayaan Melayunya.

Hingga saat ini, ada anggapan dari orang yang bukan Betawi bahwa bahasa Betawi itu mudah. Apabila sudah mengganti bunyi [a] atau [ah] pada akhir sebuah kata dengan bunyi [e], berarti penutur sudah berbahasa Betawi, begitu juga apabila penutur sudah mengganti sufiks (akhiran) -kan dan -I dengan sufiks -in, serta apabila sudah menggunakan kata gue dan lu untuk menyatakan "saya" dan "kamu". Anggapan ini sungguh keliru karena pertama bahasa Betawi mempunyai beberapa variasi lafal untuk bunyi [a] dan [ah] yang terdapat pada bahasa Indonesia atau bahasa Melayu umum. Begitu juga bahasa Betawi mempunyai sistem kosakata sendiri yang khas yang tidak sama dengan sistem kosakata bahasa Indonesia atau bahasa Melayu umumnya. Selain itu, bahasa Betawi memiliki sistem sosial tertentu di dalam penggunaannya sehingga penutur tidak bisa menggunakan sebuah kata seperti penutur menggunakan dalam bahasa Indonesia atau Melayu umum.

Menurut Chaer (2012) bahasa Betawi merupakan salah satu dialek areal dari bahasa Melayu. Sebagai sebuah dialek areal, bahasa Betawi tentu mempunyai perbedaan dengan dialek-dialek areal Melayu lainnya, seperti dengan dialek Melayu Riau, dialek Melayu Banjar, atau dengan dialek Melayu Manado. Lalu, karena wilayah penggunaan dialek Melayu Betawi ini cukup luas, dari Tangerang sebelah barat, Ciputan dan Gandaria di sebelah selatan, BekasiTambun di sebelah timur dan Pantai Utara Jakarta di sebelah utara, maka bahasa Betawi ini memiliki perbedaan baik dalam lafal maupun dalam sejumlah kosakata.

Menurut Muhadjir (2000) bahasa Betawi adalah salah satu variasi bahasa Melayu lokal yang berjumlah puluhan di Indonesia, sedangkan bahasa Melayu sendiri juga hanya satu anggota dari ratusan bahasa daerah yang hidup di Indonesia. Menurut Muhasyim \& Iwan (2011) bahasa formal dari suku Betawi adalah bahasa Indonesia. Namun, untuk bahasa informal atau bahasa percakapan sehari-hari, suku Betawi menggunakan bahasa Indonesia dengan dialek Betawi. Dialek Betawi sendiri terbagi atas dua jenis, yaitu dialek Betawi 
Tengah dan dialek betawi Pinggir. Dialek Betawi tengah cukup kental dengan bunyi "é" sedangkan dialek Betawi pinggir indentik dengan bunyi "a". Dialek Betawi tengah sering kali dianggap sebagai dialek Betawi sejati karena berasal dari tempat bermulanya Kota Jakarta. Sedangkan dialek Betawi pinggiran adalah perpaduan dari daerah dekat dengan daerah Jakarta.

Dalam penelitian ini karena berada di wilayah Kecamatan Cipondoh Tangerang, maka menurut Chaer (2012) termasuk ke dalam dialek bahasa Betawi kategori Logat IV sebab dulu dituturkan oleh penduduk Betawi di daerah pinggiran yang sangat luas dari Tangerang, Ciputan, Gandaria, Pondok Gede, dan Bekasi. Dalam Logat IV ini tidak mengenal bunyi [è̀]. Kata apa, berapa, rumah dan darah dilafalkan menjadi [apah], [berapah], [rumah] dan [darah]. Khususnya di Kampung Gondrong Kota Tangerang yang kita ketahui sebagian besar masyarakat Tangerang menggunakan bahasa Sunda dialek Banten, tetapi karena mobilisasi yang tinggi antara warga Tangerang dan Jakarta serta terdapatnya banyak warga yang berbahasa Betawi di daerah tersebut, maka terjadilah kontak bahasa yang mengakibatkan adanya interferensi. Untuk itu, dalam penelitian akan difokuskan pada masalah Bagaimanakah bentuk interferensi bahasa Betawi yang terjadi di Kampung Gondrong Kota Tangerang? Dengan tujuan mendeskripsikan bentukbentuk interferensi bahasa Betawi yang terjadi di Kampung Gondrong Kota Tangerang. Harapannya menjadi dasar untuk tetap melestarikan bahasa daerah khususnya bahasa Betawi dengan mengkaji interferensi bahasa Betawi.

\section{B. Metode Penelitian}

Metode penelitian yang digunakan dalam mengungkap bentuk interferensi bahasa Betawi di Kampung Gondrong Kota Tangerang yaitu metode deskriptif kualitatif. Moleong (2007) berpendapat penelitian kualitatif adalah penelitian yang bermaksud untuk memahami fenomena tentang apa yang dialami oleh subjek penelitian misalnya perilaku yang secara holistik, dan dengan cara deskripsi dalam bentuk kata-kata dan bahaha, pada suatu konteks khusus yang alamiah 
dan dengan memanfaatkan berbagai metode alamiah. Menurut Sudaryono (2016) analisis deskriptif ditujukan untuk mendeskripsikan suatu keadaan atau fenomenafenomena apa adanya. Analisis ini bersifat pembahasan mendalam tentang isi suatu informasi tentang obyek penelitian. Menurut Sulaeman (2019), dalam penelitian deskriptif etnografi data yang didapatkan berupa senarai kata-kata penutur asli. Dari pendapat tersebut metode deskriptif ini digunakan untuk mendeskripsikan dan menganalisis data tentang interferensi bahasa Betawi di Kamapung Gondrong Kota Tangerang.

Menurut Lofland (1984) dalam Moleong (2007) sumber utama data dalam penelitian kualitatif adalah kata-kata dan tindakan selebihnya adalah data tambahan seperti dokumen dan lain-lain. Data yang digunakan dalam penelitian ini adalah interferensi bahasa Betawi di Kampung Gondrong. Sumber data yang digunakan dalam penelitian ini berasal dari rekaman percakapan masyarakat Gondrong. Subjek penelitian dalam penelitian ini adalah anggota kelompok penelitian dan dibantu oleh instrumen pendukung lainnya, seperti buku-buku mengenai teori kebahasaan, buku-buku mengenai bahasa Betawi dan sumbersumber lainnya.

Teknik pengumpulan data menggunkan teknik rekam dan catat. Teknik rekam dengan mendengarkan dan merekam percakapan masyarakat Betawi di Kampung Gondrong. Sedangkan teknik catat dengan mencatat ulang tuturan kata yang menjadi data penelitian. Setelah data terkumpul maka data tersebut dianalisis dengan cara berikut: (1) mengidentifikasi data sesuai dengan konsep bahasa Betawi, (2) mengklasifikasi data berdasarkan teori yang menjadi acuan, (3) menganalisis data dengan melihat interferensi bahasa Betawi dengan mencatat kata-kata atau kalimat-kalimat yang berbeda, (4) Menginterprestasikan data yang sudah dianalisis sesuai denga teori, dan (5) Menyimpulkan hasil deskripsi data dengan menulis laporan. Teknik pengabsahan data yang digunakan dalam penelitian ini adalah teknik pengecekan teman sejawat dan kecukupan referensi. 


\section{Hasil Penelitian dan Pembahasan}

\section{Hasil Penelitian}

a. Interferensi pada Prefiks (Awalan)

Interferensi morfologi bahasa Betawi di Kampung Gondrong Kota Tangerang dalam bentuk prefiks (awalan) dapat ditunjukkan pada tabel berikut.

Tabel 1. Interferensi Morfologi Bahasa Betawi di Kampung Gondrong dalam Bentuk Prefiks

\begin{tabular}{ccll}
\hline No. & \multicolumn{1}{c}{ Prefiks } & \multicolumn{1}{c}{ Kata } & Makna \\
\hline 1. & Nge + dumel & Ngedumel & Menahan amarah \\
\hline 2. & Di + comot & Dicomot & Diambil \\
\hline 3. & Di + kokot & Dikokot & Dikunci \\
\hline 4. & Di + bawa & Dibawa & Dibawa
\end{tabular}

b. Interferensi pada Sufiks (Akhiran)

Interferensi morfologi bahasa Betawi di Kampung Gondrong Kota Tangerang dalam bentuk sufiks (akhiran) dapat ditunjukkan pada tabel berikut.

Tabel 2. Interferensi Morfologi Bahasa Betawi di Kampung Gondrong dalam Bentuk Sufiks

\begin{tabular}{|c|c|c|c|}
\hline No. & Sufiks & Kata & Makna \\
\hline 1. & Sedia + in & Sediain & Menyediakan \\
\hline 2. & Nama + nya & Namanya & Namanya \\
\hline 3. & Seduh + in & Seduhin & Menyeduh \\
\hline 4. & Minum + in & Minumin & Memberi minuman \\
\hline 5. & Pikir + in & Pikirin & Memikirkan \\
\hline 6. & Entar + an & Entaran & Nanti \\
\hline 7. & Erem + in & Eremin & Dihangatkan \\
\hline 8. & Aron + in & Aronin & Menanak nasi \\
\hline 9. & Cetek + in & Cetekin & Menyalakan \\
\hline 10. & Pikir + an & Pikiran & Pikiran \\
\hline 11. & Rejeki + nya & Rejekinya & Rezekinya \\
\hline 12. & Saut + in & Sautin & Menjawab \\
\hline 13. & $\mathrm{Doa}+$ in & Doain & Mendoakan \\
\hline
\end{tabular}

Silampari Bisa: Jurnal Penelitian Pendidikan Bahasa Indonesia, Daerah, dan Asing Vol. 3, No. 2, 2020 
c. Interferensi pada Konfiks (Campuran)

Interferensi morfologi bahasa Betawi di Kampung Gondrong Kota

Tangerang dalam bentuk konfiks (campuran) dapat ditunjukkan pada tabel berikut.

Tabel 3. Interferensi Morfologi Bahasa Betawi di Kampung Gondrong dalam Bentuk Konfiks

\begin{tabular}{clll}
\hline No. & \multicolumn{1}{c}{ Konfiks } & \multicolumn{1}{c}{ Kata } & \multicolumn{1}{c}{ Makna } \\
\hline 1. & Ke + banget + an & Kebangetan & Keterlaluan \\
\hline 2. & Se + rabut + an & Serabutan & Tidak pasti \\
\hline 3. & Di + bilang + in & Dibilangin & Menasehati \\
\hline
\end{tabular}

d. Interferensi Bahasa Betawi ke dalam Bahasa Indonesia

Interferensi morfologi bahasa Betawi ke dalam bahasa Indonesia daapat dicontohkan pada beberapa kata berikut.

Tabel 4. Interferensi Morfologi Bahasa Betawi ke Dalam Bahasa Indonesia di Kampung Gondrong

\begin{tabular}{|c|c|c|c|}
\hline No. & Bahasa Betawi & Bahasa Indonesia & Keterangan \\
\hline 1. & Waya & Waktu & Kata yang menunjukkan waktu. \\
\hline 2. & Titet & Pagi & $\begin{array}{lccc}\text { Kata yang } & \text { digunakan } & \text { untuk } \\
\text { menyatakan waktu pagi hari. } & \\
\end{array}$ \\
\hline 3. & Dur & Menjelang maghrib & $\begin{array}{l}\text { Kata yang digunakan untuk } \\
\text { menunjukkan waktu telah menjelang } \\
\text { malam. }\end{array}$ \\
\hline 4. & Bini & Istri & $\begin{array}{l}\text { Kata yang menunjukkan untuk } \\
\text { sebutan dari pasangan (sah) dari } \\
\text { mempelai pria. }\end{array}$ \\
\hline & Laki & Suami & $\begin{array}{l}\text { Kata yang menunjukkan untuk } \\
\text { sebutan dari pasangan (sah) dari } \\
\text { mempelai wanita. }\end{array}$ \\
\hline 6. & llokan & Masa & Kata yang menunjukan kepastian. \\
\hline & Pegih & Pergi & $\begin{array}{l}\text { Kata yang menunjukkan untuk } \\
\text { meninggalkan tempat. }\end{array}$ \\
\hline & Saban & Setiap & 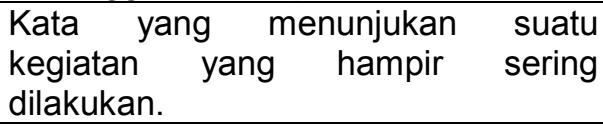 \\
\hline 9. & Aya & Saya & $\begin{array}{l}\text { Kata yang menunjukan untuk } \\
\text { mengajukan diri. }\end{array}$ \\
\hline & Aronin & Menanak nasi & $\begin{array}{l}\text { Kata yang digunakan untuk memasak } \\
\text { nasi. }\end{array}$ \\
\hline & Gidah & Silahkan & $\begin{array}{lll}\text { Kata yang digunakan untuk } \\
\text { mengizinkan. }\end{array}$ \\
\hline 12. & Bale & $\begin{array}{l}\text { Tempat duduk terbuat } \\
\text { dari papan (Lebar) }\end{array}$ & $\begin{array}{l}\text { Kata yang digunakan untuk } \\
\text { menunjukkan tempat duduk besar. }\end{array}$ \\
\hline 13. & Jia & Dia & $\begin{array}{l}\text { Kata ganti yang digunakan untuk } \\
\text { orang ke- } 2 \text {. }\end{array}$ \\
\hline 14. & Kupi & Kopi & $\begin{array}{l}\text { Kata yang digunakan untuk minuman } \\
\text { kafein. }\end{array}$ \\
\hline
\end{tabular}

Silampari Bisa: Jurnal Penelitian Pendidikan Bahasa Indonesia, Daerah, dan Asing Vol. 3, No. 2, 2020 


\begin{tabular}{|c|c|c|c|}
\hline 15. & Eremin & Menghangatkan & $\begin{array}{l}\text { Kata yang digunakan untuk } \\
\text { menghangatkan telur. }\end{array}$ \\
\hline 16. & Cetekin & $\begin{array}{l}\text { Menyalakan } \\
\text { benda }\end{array}$ & $\begin{array}{l}\text { Kata yang menunjukkan untuk } \\
\text { menyalakan suatu benda. }\end{array}$ \\
\hline 17. & Uyup & Minum & $\begin{array}{l}\text { Kata yang digunakan untuk } \\
\text { memasukkan air ke dalam mulut. }\end{array}$ \\
\hline 18. & Dikokot & Dikunci & $\begin{array}{l}\text { Kata yang biasa digunakan untuk } \\
\text { mengunci atau menggembok suatu } \\
\text { benda. }\end{array}$ \\
\hline 19. & $\mathrm{Nti}$ & Nanti & $\begin{array}{l}\text { Kata yang digunakan untuk } \\
\text { menunjukkan waktu yang tidak lama } \\
\text { atau menyatakan kelak. }\end{array}$ \\
\hline 20. & Dicomot & Diambil & $\begin{array}{l}\text { Kata yang digunakan untuk } \\
\text { memegang sesuatu. }\end{array}$ \\
\hline 21. & Begimana & Bagaimana & $\begin{array}{l}\text { Kata yang digunakan untuk } \\
\text { menanyakan suatu perbuatan. }\end{array}$ \\
\hline 22. & Pan & Kan & $\begin{array}{l}\text { Kata yang digunakan untuk } \\
\text { mempertegas pernyataan. }\end{array}$ \\
\hline 23. & lyeng-iyeng & Tidak peduli & $\begin{array}{l}\text { Kata yang biasa digunakan untuk } \\
\text { tidak } \quad \text { menghiraukan } \\
\text { perkataan atau perbuatan. }\end{array}$ \\
\hline 24. & Wadon & Perempuan & $\begin{array}{l}\text { Kata yang digunakan yang merujuk } \\
\text { pada seseorang yang berkelamin } \\
\text { perempuan. }\end{array}$ \\
\hline 25. & Demen & Suka & $\begin{array}{l}\text { Kata yang digunakan untuk } \\
\text { menyatakan perasaan senang hati. }\end{array}$ \\
\hline 26. & Barin & Biarkan & $\begin{array}{l}\text { Kata yang biasa digunakan untuk } \\
\text { tidak menghiraukan sesuatu } \\
\text { perkataan atau perbuatan. }\end{array}$ \\
\hline 27. & Sono & Sana & $\begin{array}{l}\text { Kata yang digunakan untuk menunjuk } \\
\text { tempat yang jauh. }\end{array}$ \\
\hline 28. & Redo & Ikhlas & $\begin{array}{llr}\text { Kata yang biasa digunakan } \\
\text { menunjukkan } & \text { ketulusan } \\
\text { seseorang. } & & \text { hati } \\
\end{array}$ \\
\hline 29. & He'eh & lya & 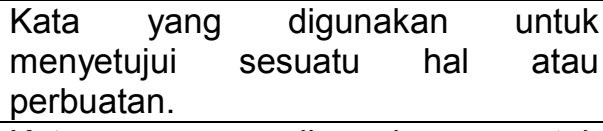 \\
\hline 30. & Ngablak & Terbuka & $\begin{array}{l}\text { Kata yang digunakan untuk } \\
\text { memberitahu sesuatu hal yang tidak } \\
\text { tertutup atau tersingkap. }\end{array}$ \\
\hline 31. & Memedi & Makhluk halus/hantu & $\begin{array}{l}\text { Kata yang menunjukan pada hal } \\
\text { mistis. }\end{array}$ \\
\hline 32. & Ampe & Sampai & $\begin{array}{l}\text { Kata yang digunakan untuk } \\
\text { menyatakan capaian/mencapai. }\end{array}$ \\
\hline 33. & Lemes & Cerewet & $\begin{array}{l}\text { Kata yang digunakan apabila } \\
\text { seseorang banyak bicara. }\end{array}$ \\
\hline 34. & Mao & Mau & $\begin{array}{l}\text { Kata yang digunakan untuk } \\
\text { menunjukkan sebuah keinginan atau } \\
\text { capaian. }\end{array}$ \\
\hline & Grobog & Lemari kecil & Benda yang terbuat dari kayu. \\
\hline 36. & Bujug & Takjub & digunakan \\
\hline
\end{tabular}

Silampari Bisa: Jurnal Penelitian Pendidikan Bahasa Indonesia, Daerah, dan Asing Vol. 3, No. 2, 2020 


\begin{tabular}{|c|c|c|c|}
\hline & & & mengungkapkan sebuah kekaguman. \\
\hline 37. & Nenteng & Bawa & $\begin{array}{l}\text { Kata yang digunakan untuk } \\
\text { mengangkat suatu benda ke tempat } \\
\text { lain. }\end{array}$ \\
\hline 38. & $\mathrm{Be}$ & Saja & $\begin{array}{lrr}\text { Kata yang digunakan } & \text { untuk } \\
\text { menyatakan selalu atau } & \text { melulu } \\
\text { melakukan kegiatan. } & & \\
\end{array}$ \\
\hline 39. & Kaga & Tidak & $\begin{array}{lccc}\text { Kata yang } & \text { digunakan untuk } & \text { tidak } \\
\text { menyetujui } & \text { sesuatu } & \text { hal } & \text { atau } \\
\text { perbuatan. } & & & \end{array}$ \\
\hline 40. & Anget & Hangat & 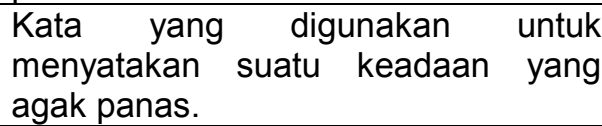 \\
\hline 41. & Lau & Lauk & $\begin{array}{l}\text { Makanan yang dimakan sebagai } \\
\text { teman nasi }\end{array}$ \\
\hline 42. & Belon & Belum & $\begin{array}{l}\text { Kata yang digunakan untuk } \\
\text { menyatakan keadaan yang } \\
\text { dalam keadaan tidak. }\end{array}$ \\
\hline 43. & Ono & Itu & $\begin{array}{l}\text { Kata yang digunakan sebagai kata } \\
\text { penunjuk. }\end{array}$ \\
\hline 44. & Saoloh & Masya Allah & Kata yang digunakan sebagai doa. \\
\hline 45. & Ngapa & Kenapa & $\begin{array}{l}\text { Kata tanya untuk menanyakan sebab } \\
\text { atau alasan. }\end{array}$ \\
\hline 46. & Ngata & Kata & $\begin{array}{l}\text { Ucapan yang dilontarkan seseorang } \\
\text { kepada orang lain. }\end{array}$ \\
\hline 47. & Piara & Pelihara & $\begin{array}{l}\text { Kata yang digunakan untuk } \\
\text { menunjukan menjaga atau merawat } \\
\text { sesuatu bisa berupa makhluk hidup } \\
\text { ataupun benda. }\end{array}$ \\
\hline 48. & Nyaut & Sahut & $\begin{array}{l}\text { Kata yang digunakan untuk menjawab } \\
\text { apabila dipanggil atau ditanya. }\end{array}$ \\
\hline 49. & Beduk & Gendang besar & $\begin{array}{l}\text { Benda berupa tong yang terbuat dari } \\
\text { kulit sapi atau kambing. }\end{array}$ \\
\hline 50. & Ngebul & Banyak asap & $\begin{array}{l}\text { Suatu keadaan dimana di suatu } \\
\text { tempat terdapat banyak asap. }\end{array}$ \\
\hline 51. & Neng & $\begin{array}{l}\text { Panggilan } \\
\text { perempuan }\end{array}$ & $\begin{array}{l}\text { Kata sapaan yang digunakan untuk } \\
\text { memanggil anak perempuan. }\end{array}$ \\
\hline & Remeng & Redup & $\begin{array}{l}\text { Kata yang digunakan untuk } \\
\text { menyatakan suatu tempat yang agak } \\
\text { gelap. }\end{array}$ \\
\hline
\end{tabular}

\section{Pembahasan}

Masyarakat Kampung Gondrong, Kota Tangerang dalam berkomunikasi mengalami interferensi morfologis bahasa Betawi dalam dialog sehari-hari. Interferensi sebagai penyimpangan norma kebahasaan yang terjadi dalam ujaran dwibahasawan yang dikarenakan adanya keakrabannya terhadap lebih dari satu bahasa, yang disebabkan karena terjadinya kontak bahasa dengan bahasa lain

Silampari Bisa: Jurnal Penelitian Pendidikan Bahasa Indonesia, Daerah, dan Asing Vol. 3, No. 2, 2020 
(Mutoharoh dkk., 2018). Terjadinya interferensi pada Masyarakat Kampung Gondrong, Kota Tangerang yang sebagian besar menggunakan bahasa Sunda dengan dialek Banten dipengaruhi oleh masyarakat Kampung Gondrong yang sebagian besar bekerja di Jakarta yang menggunakan bahasa Betawi serta banyak juga orang Betawi yang sudah menetap di Kampung Gondrong sejak lama. Selain itu, banyak juga masyarakat dari Jakarta yang sering berkunjung dan bekerja di Tangerang sehingga terjadilah kontak bahasa antara bahasa Sunda dengan bahasa Betawi sehingga tejadilah interferensi bahasa Betawi. Hal ini sangat lumrah karena antara Tangerang dengan bahasa Sunda dialek Banten dan Jakarta dengan bahasa Betawi saling membutuhkan tenaga kerja dan faktor lain seperti terjadinya mobilisasi keluarga dan terjadinya perdagangan.

Masyarakat di Kampung Gondrong juga memiliki kemampuan dalam menggunakan dua bahasa lebih atau disebut dengan masyarakat bilingual. Kemampuan dua bahasa yang sangat menonjol yaitu bahasa Sunda dialek Banten dan bahasa Betawi. Masyarakat yang bilingual inilah yang juga mengakibatkan terjadinya interferensi bahasa Betawi di Kampung Gondrong, Kota Tangerang (Suherman \& Sulaeman, 2020).

Beberapa bentuk interferensi yang terdapat pada dialog adalah bentuk kata dan imbuhan (afiks). Bentuk imbuhan yang terinferferensi adalah bentuk prefiks, sufiks, dan konfiks, dari struktur bahasa Betawi penggunaanya dalam masyarakat terdapat: 1) struktur bahasa di Kampung Gondrong Kota Tangerang sama dengan bahasa standar masing-masing, terutama yang berkaitan dengan intonasi; dan 2) perbedaan mencolok lainnya berhubungan dengan kosakata. Antara kosakata dialek Betawi di Jakarta wilayah tengah dengan Jakarta wilayah pinggiran berbeda. Kosakata itu sekaligus menjadi ciri khas (dialek) bahasa di Kampung Gondrong Kota Tangerang. Kesamaan struktur bahasa dan intonasi bahasa Sunda di Kampung Gondrong dan bahasa Betawi di Jakarta juga penentu terjadinya interferensi. Hal ini dikarenakan salah satu faktor terjadinya interferensi 
adalah kesamaan struktur gramatikalnya atau disebut interferensi gramatikal (Effendy, 2017; Sulaeman, 2017).

\section{Simpulan}

Masyarakat Kampung Gondrong dalam berkomunikasi terdapat interferensi morfologis bahasa Betawi dalam dialog sehari-harinya. Adapun bentuk-bentuk interferensi yang terdapat pada dialog adalah bentuk kata dan imbuhan (afiks). Bentuk imbuhan yang terinterferensi adalah bentuk prefiks, sufiks, dan konfiks, dari struktur bahasa Betawi penggunaanya dalam masyarakat terdapat: 1) struktur bahasa di Kampung Gondrong Kota Tangerang sama dengan bahasa standar masing-masing, terutama yang berkaitan dengan intonasi; dan 2) perbedaan mencolok lainnya berhubungan dengan kosakata. Antara kosakata dialek Betawi di Jakarta wilayah tengah dengan Jakarta wilayah pinggiran berbeda. Kosakata itu sekaligus menjadi ciri khas (dialek) bahasa di Kampung Gondrong Kota Tangerang.

\section{Daftar Pustaka}

Alfianika, N. (2015). Bahasa Betawi dan Gaya Bahasa Repetisi dalam Ceramah Ustad Yusuf Mansur Program Wisata Hati di ANTV. Gramatika STKIP PGRI Sumatera Barat, 1(1). doi:10.22202/jg.2015.v1i1.1161

Alfianika, N. 2016. Bahasa Betawi dan Gaya Bahasa Repetisi dalam Ceramah Ustad Yusuf Mansur Program Wisata Hati di ANTV. Vol. 1i1. No. 1161. Jurnal Gramatika : STKIP PGRI Sumatera Barat.

Chaer, A. \& Agustina, L. (2010). Sosiolinguistik Perkenalan Awal. Jakarta: Rineka Cipta.

Chaer, A. (2012). Folklor Betawi Kebudayaan dan Kehidupan Orang Betawi. Depok: Masup Jakarta. 
Dewi, F. I., Akbar, D. M., \& Suntini, S. (2020). Prinsip Kerja Sama dalam Dialog Lenong Betawi 'Anak Durhaka'. Fon: Jurnal Pendidikan Bahasa Dan Sastra Indonesia, 16(2), 48. doi:10.25134/fjpbsi.v16i2.3508

Effendy, M. H. (2017). Interferensi Gramatikal Bahasa Madura ke Dalam Bahasa Indonesia. Dialektika : Jurnal Bahasa, Sastra, dan Pendidikan Bahasa dan Sastra Indonesia, 4(1), http://journal.uinjkt.ac.id/index.php/dialektika/article/view/6997

Moleong, L. J. (2007). Metodologi Penelitian Kualitatif. Bandung: PT. Remaja Rosdakarya.

Muhadjir. (2000). Bahasa Betawi: Sejarah dan Perkembangannya. Jakarta: Yayasan Obor Indonesia.

Muhasyim, H. \& Iwan, S. (2011). Mengenal Seni dan Budaya Betawi. Jakarta: Lestari Kiranatama.

Muhasyim, H. (2011). Sejarah dan Tokoh-tokoh Betawi. Jakarta: Lestari Kiranatama.

Mutoharoh, M., Sulaeman, A., \& Goziyah, G. (2018). Interferensi Morfologi dalam Karangan Narasi Mahasiswa Thailand Semester IV Pendidikan Bahasa dan Sastra Indonesia FKIP Universitas Muhammadiyah Tangerang. Silampari Bisa: Jurnal Penelitian Pendidikan Bahasa Indonesia, Daerah, dan Asing, 84-97. https://doi.org/https://doi.org/10.31540/silamparibisa.v1i1.10

Noermanzah, N. (2019). Bahasa sebagai Alat Komunikasi, Citra Pikiran, dan Kepribadian. Seminar Nasional Pendidikan Bahasa dan Sastra, Prosiding Seminar Nasional Bulan Bahasa (Semiba), 307, https://ejournal.unib.ac.id/index.php/semiba/article/view/11151/5537

Sudaryono. (2016). Metode Penelitian Pendidikan. Jakarta: Prenamedia Group.

Suhardi. (2013). Pengantar Linguistik Umum. Yogyakarta: Ar-Ruzz Media.

Suherman, A., \& Sulaeman, A. (2020). Bilingualism in Gadis Pantai Novel by Pramoedya Ananta Toer. Journal of English Education and Teaching, 4(2), 264-277. doi:10.33369/jeet.4.2.264-277 
Sulaeman, A. (2017). Structure of Sunda in Tangerang Regency and the Territory of Use. Indonesian Language Education and Literature, 3(1), 15. doi:10.24235/ileal.v3i1.1555

Sulaeman, A. (2019). Bahasa Slang Generasi Muda dalam Media Sosial di Era Milenial. In Seminar Nasional Pendidikan Bahasa dan Sastra (pp. 45-54).

Tiani, R. (2018). Bentuk Pergeseran Dialek pada Masyarakat Betawi. Nusa: Jurnal Ilmu Bahasa dan Sastra, 13(4), 614. doi:10.14710/nusa.13.4.614-622 